\title{
MISCELLANEA EX ARCHIVO CORONAE REGNI BOHEMIAE. DIPLOMATICKÝ PŮVOD A VYPOVÍDACÍ HODNOTA LISTIN DVOU SLEZSKÝCH MĚST PAČKOVA A GRODKOVA Z ROKU 1383
}

\author{
IVAN HLAVÁČEK
}

\section{MISCELLANEA EX ARCHIVO CORONAE REGNI BOHEMIAE. THE DIPLOMATIC ORIGIN AND INFORMATIVE VALUE OF CHARTERS ISSUED BY TWO SILESIAN TOWNS, PACZKÓW AND GRODKÓW, IN 1383}

\begin{abstract}
This contribution examines three documents kept in the Archives of the Bohemian Crown, which were issued by the Silesian towns of Nisa, Grodków, and Paczków, and addressed to Wenceslaus IV, the King of Bohemia, to whom these towns promise loyalty and aid. The author follows the origins and context of these documents, whose drafting was influenced by the Bishop of Wroclaw and his chancellor.
\end{abstract}

Keywords: Charters - Middle Ages - Archives of the Bohemian Crown - Wenceslaus IV - Silesia Nisa - Grodków - Paczków

DOI: $10.14712 / 23365730.2018 .36$

Je velmi dobře známo, že Český korunní archiv, zvaný též Archivem sv. Václava (dále jen AČK), je nejrozsáhlejším a také nejdůležitějším listinným archivem starého českého státu. Je ovšem též známo, že nejde o jednotný celek, i když klíčový materiál tvoří písemnosti, jejichž př́ijemcem je český stát, potažmo český panovník. Př́ležitostně do něho totiž porůznu vplývaly - organicky i náhodně (aspoň tak se to může dnes jevit, protože patřičná dokumentace zdaleka není taková, jak bychom si práli) - různé jednotliviny i celé archivy ve své měnící se funkci. Mohlo by se zdát, že významu tohoto archivu v důsledku toho odpovídá pozornost, která mu byla a je věnována českou historiografií, ${ }^{1}$ ale je to do značné míry klam.

1 Výše řečené ovšem neznamená, že by mu pozornost věnována nebyla, naopak. Dálo a děje se tak ale po významném náběhu těsně před druhou světovou válkou spíše nesoustavně, respektive se pro soustavné studium vytvářejí různé předpoklady. Z literatury upozorňuji jen na to nejdůležitější. Základem je kompletní hlubotisková edice všech originálů, zatím do roku 1468, doprovázená textovými sešity, podávajícími jejich záhlavní regesty, které zatím chybí k sešitům VI-1,2: (řada editorů), Archiv České koruny. Edice faksimiliii. = Archivum Coronae regni Bohemiae. Editio diplomatum phototypica, zatím svazky I-VI/2, Praha 1982nn., dostupné také elektronicky: $<$ https://books.google.cz/books/about/Archiv_\%C4\%8Cesk\%C3\%A9_Koruny_edice_faksimili\%C3\%AD.html?id=cGrgAQAACAAJ\&redir_esc=y $>$ (ověřeno 18.3. 2018). Rozsáhlá historie fondu vznikla prací Rudolfa Kosse, z jehož pozůstalosti knihu vydal Otakar BAuer, Archiv Koruny české, I, Dějiny archivu, Praha 1939. Šlo tu o pilotní svazek velkého projektu, z něhož se uskutečnil pouze zlomek. $Z$ něho nás zde bude zajímat především regestář Antonína Haase, který v tomto rámci vydal vedle originálního listinného materiálu do smrti Jana Lucemburského zejména regesta originálních listin z doby Václava IV.: Antonín HaAs (ed.), 
A ještě méně než si to zaslouží je v současnosti vnímán historiografiemi sousedních zemí, ač tomu tak dřive nebývalo, $i$ když tehdy šlo vlastně výlučně o archivně historicky nenáročné využití obsahové. Výše zmíněná ,jen“ ovšem neznamenají, že je v něm, pokud jde o genezi a funkci písemností, které tam byly ukládány, možno „číst“ bez problémů. Ba leckdy právě naopak se s otazníky, pokud čteme pozorně, setkáváme doslova na každém kroku a často v netušených souvislostech. Je tomu tak i proto, že přes jeho značný rozsah nejde o archiv, který by byl dochován intaktně a ve stejné kvalitě. Znamená to, že vedle dvou a půl tisíce originálů se v něm nalézá další řada listin jen v opisech v korunních kopiářích, jiné písemnosti se naopak dostaly do cizích archivů. Nadto se musí předpokládat i různá, nepochybně také dosti početná, ale těžko odhadnutelná deperdita, často také podmíněná různými extradicemi. Nebot' tento archiv byl mimořádně živým organismem, který velmi přesně reagoval na všeliké změny majetkové či státoprávní povahy tak, jak je s sebou nesl každodenní politický život. „Klidu“ mu nedopřály ani různé vnitro- či zahraničněpolitické turbulence, v jejichž důsledku leckdy měnil místo svého uložení se všemi negativy, která to přinášelo.

V následujících řádcích ${ }^{2}$ bych se chtěl pokusit upozornit na jednu diplomatickou zvláštnost, která sice na jedné straně pozorného čtenáře bije do očí, ale na straně druhé jí dosud nebyla věnována pozornost. Jde ovšem o záležitost historicky do jisté míry okrajovou, regionální, ukazuje se ale znovu a znovu, že vznik středověké (ale ovšem i novověké) listinné jednotliviny se mohl svou genezí odlišovat od zdánlivě neproblémového svědectví, které o sobě na první pohled vydává. Zároveň však může upozorňovat nejen na nedochované písemnosti, o nichž tak získáváme aspoň jakousi povědomost, ale i na takové okolnosti, které naznačují netušenou a někdy svébytnou vnitřní propojenost při úředním jednání, o nichž bychom jinak neměli ani potuchy. A nadto může ukázat všelijaké tlaky, vazby, vztahy a další více či méně (ne)symptomatické souvislosti.

Ale ještě než obrátím pozornost k vlastnímu tématu, rád bych upozornil jako na jisté obecné memento na mimořádné, ba do značné míry bizarní svědectví listiny rakouského vévody Albrechta III., jíž se zdánlivě exaktně v roce 1384 obnovuje (či vlastně teprve uvádí v konkrétní život) univerzita vídeňská. Tato písemnost totiž vznikala doslova řadu let, ${ }^{3}$ nejen jako vlastní text, ale vzhledem k časové disparátnosti při obsahovém naplňování

Archiv Koruny české, V, Katalog listin z let 1379-1437, Praha 1947 (dále A. HaAs /ed./, Katalog). Celkový přehled originálních listin ve formě záhlavních regestů vydal týž autor v rámci řady inventářů a katalogů fondů tehdejšího Státního ústředního archivu ve formě jen rozmnožených textů jako 14. svazek: Antonín HAAs (ed.), Archiv České koruny 1158-1935, Praha 1961. Chybí tedy regestář AČK zejména pro dobu Karlovu, přičemž tyto listiny jsou - ovšem rozptýleně - integrovány (dnes už jen na malé výjimky) do Českomoravských regest jeho doby. Nově pak podává stručnou informaci v rámci průvodce po Národním archivu Denko ČUMLIVSKI, Státni ústřední archiv v Praze. Prüvodce po archivních fondech a sbírkách, I/1, Praha 1997, s. 96nn. Několik speciálních analytických studií souvisí s úvahami nad strukturou tohoto archivu. Speciální edice budou dle potřeby uvedeny dále.

2 Měl jsem př́ležitost věnovat pozornost Korunnímu archivu zatím ve dvou drobných miscelách. V první šlo o částečnou extradici sileziakálních listin do Vratislavi, v druhé stati o jmenovací mandáty pro krajské poprávce z ledna roku 1405: Ivan HLAVÁČEK, Vratislavská epizoda českého Korunního archivu, Archivní časopis 30, 1980, s. 100-106; TÝž, př́loha stati König Wenzel (IV.) und seine zwei Gefangennahmen (Spiegel seines Kampfes mit dem Hochadel sowie mit Wenzels Verwandten um die Vorherrschaft in Böhmen und Reich), in: Quaestiones medii aevi novae 18, 2013, s. 115-149.

3 Christian Lackner, Möglichkeiten und Perspektiven diplomatischer Forschung. Zum Privileg Herzog Albrechts III. für die Universität Wien vom Jahre 1384, Wien - Weimar - Köln 2013. Zdánlivě vzdálený ,pprípad“ uvádím jako metodologické obecně diplomatické memento, opravňující minuciézní práci i v oblasti pozdního stř̌edověku, která je leckdy podceňována. Zejména právě jde o sledování písařských rukou a jejich eventuálních změn. 
i jako fyzický originál, nebot' prvotní založení univerzity Rudolfem IV. v roce 1365 bylo pouze teoretickým aktem.

Přenesme se ale do prostředí zemí Koruny české, přesněji do velmi právně komplikovaného vztahu slezského, či spíše slezských prostředí k pražskému královskému dvoru. Ten byl v dobách Jana Lucemburského, Karla IV. a jeho syna Václava IV. obecně nejen velmi úzký, ale různými - i osobními - kontakty se stále prohluboval a utužoval, byt' akcenty se přesouvaly. ${ }^{4}$ Tomu také odpovídá velký počet listin slezských vydavatelů různého sociálního původu, jenž v důsledku toho nalezl své útočiště právě v AČK. Listujeme-li výše zmíněným svazkem Haasova katalogu tohoto fondu pro dobu Václava IV. (který ale katalogem v plném smyslu toho slova není, protože jeho regesty zdaleka ne vždy postihují plný obsah listin, ba někdy se dokonce dovídáme i věci, které v textu nejsou), narazíme tam na dvě „fádní“ latinské listiny z 27. května 1383 (dále je označuji jako D a E). Jde o zdánlivě bagatelní texty.

Dle intitulace jde o městské listiny, a to měst Grodkov (Grodków, Grottkau) a Pačkov (Paczków, Patschkau). Ta slibují na príkaz vratislavského biskupa Václava (knížete Lehnického) stálou podporu českému králi Václavu IV., jeho potomkům a stoupencům, majícím statky ve vratislavské diecézi, a zejména to, že nevpustí do svého města žádného jeho nepř́itele mimo oblast vratislavské diecéze..$^{5}$ Ovšem v př́padě, že by král, ale i město Vratislav tamního biskupa, jeho kapitulu a diecézní klérus utiskovali, postaví se na jejich obranu, stejně tak jako to má učinit král, kdyby tak nečinilo město Vratislav samo. Tato obrana se však vztahuje i na města samotná, tedy na Pačkov a/nebo Grodkov, která se po nastalém uklidnění poměrů opět poddávají českému králi. ${ }^{6}$ Může se totiž zdát, že tato dost komplikovaná ustanovení jsou odrazem složitosti předchozích místních poměrů, kdy došlo v souvislosti s vyhlášením místního interdiktu jednak k zásahu kurie, jednak k bezprostřední ingerenci

4 Není třeba tu uvádět soustavněji př́íslušnou obecnou literaturu, která by rekapitulovala tento postupný, ale současně variabilní proces utužování lenních vazeb jednotlivých slezských knížectví s českým státem, což se jejich prostřednictvím přenáší na jejich různé podřízené složky, tedy zejména na města. Stačí, když se odkáže na níže citovaný Handbuch der historischen Stätten (viz pozn. 5) a tam citovanou literaturu, ale zejména pak na výstupy velkého projektu Lenky Bobkové o vedlejších zemích Koruny české, doprovodné svazky velké výstavy pražské Národní galerie Helena DÁŇová - Jan KLíPA - Lenka StolÁrovả (eds.), Slezsko - země Koruny české, A-B, Historie a kultura 1300-1740, Praha 2008. Nicméně mne zde zajímající problematika tam nepřekvapivě není, až na výjimky (Mlada Holá, Bezprostředni majetky a vztahy českých králů ve Slezsku v letech 1331-1378 a jejich správa, in: tamtéž, s. 129nn.), ani dotčena. Pro pochopení zásadních poměrů církevních odkazuji zejména na sice již starší, nicméně stále platné výklady Tadeusze SiLNICKIEGo, Dzieje i ustrój kościola katolickiego na Śląsku do końca w. XIV, Warszawa 1953 (reprint vydání z roku 1939, tehdy v rámci sborníkové práce Historia Śląska od najdawniejszych czasów do roku 1400, II/1), s. $251 \mathrm{nn}$. Třeba ale opravit na s. 285 datum listiny z 6. ledna na rok 1383 (jak je správně na s. 283). Je ovšem - vedle dalších - vydána v Praze a nikoliv v Grodkově.

5 A. HAas (ed.), Katalog, č. 34 a 35. Zevrubnější regesty viz Colmar GRünHAGEN - Heinrich MARKGRAF (eds.), Lehns- und Besitzurkunden Schlesiens und seiner einzelnen Fürstenthümer im Mittelalter, II, Leipzig 1883, s. 238n, č. 40 a 41. Srov. o těchto městech informativně Hugo WECZERKa (ed.), Handbuch der historischen Stätten - Schlesien, Stuttgart 2003, s. 162-164 a 393-396. Vzájemné vzdálenosti vzdušnou čarou jsou mezi nimi cca $35 \mathrm{~km}$, z Pačkova do Vratislavi je cca $80 \mathrm{~km}$ a z Grodkova cca $50 \mathrm{~km}$. Výslovně ale musím konstatovat, že jsem neměl možnost nahlédnout do lokální literatury ani německé, ani polské. Nicméně se mohu důvodně domnívat, že v ní je nanejvýš reflektován bezproblémový obsah uvedených listin.

6 Listinná svědectví jsou vydána in: C. GrüNhAGEN - H. MARKGRAF (eds.), Lehns- und Besitzurkunden Schlesiens, II, jejich editoři vycházejí rovněž z listin chovaných v AČK. Protože tato publikace je v Haasově katalogu, ale i v dalších zde uváděných mladších edicích v plnosti citována, uvádím ji pouze tehdy, je-li záhodno upozornit na celý text. 
krále Václava a drsnému vystoupení českého vojenského kontingentu. ${ }^{7}$ To vše se na nich sice nepochybně podepsalo, ale situace se ukazuje složitější. Pokud jde o situaci ve Vratislavi (městě i biskupství, ale i v kapitule), šlo o několikerou nevraživost. Ta je v historii známa jako tzv. „,vratislavská popská vojna“, která vypukla mezi městem a kapitulou ohledně dodávek piva na „Ostrov Tumski“", tedy do dómské kapituly. To ovšem město považovalo za porušení svých privilegií. Následné vyhlášení interdiktu kapitulou přimělo i krále Václava IV. k tomu, aby do tohoto sporu razantně vstoupil. K tomu se pak připojily i tenze související s uvolněním se biskupského stolce úmrtím Přeclava z Pogorelly (†1376), nepotvrzením volby Dětřicha z Klatov, následným transferem Jana ze Středy z Olomouce, který ale zemřel ještě před převzetím úřadu, a posléze nástupem knížete Václava Lehnického v dubnu roku 1382. Tím se situace od konce roku 1382 postupně uklidňovala. V tomto kontextu pak došlo k normalizaci poměrů, jejichž produktem jsou i obě zde tematizované listiny, jež reagovaly na královu vstřícnost, která byla doprovázena různými hospodářskými výhodami biskupství a kapitule. Ti jej pak přijímají za svého nejvyššího pána a ochránce. ${ }^{8}$ Mohlo by se zdát, že v obou těchto listinách šlo v podstatě o akty reagující na výše uvedené milosti, i když formulují prakticky všechny v úvahu přicházející varianty chování pro př́pad, kdyby opět vypukly nevraživosti mezi městem, tamním duchovenstvem a eventuálně do toho vstupujícím králem. Současně stvrzují každodenní právní a správní aktivity politického života. ${ }^{9}$ Věc se ale ve světle listin D a E jeví jinak, či spíše jde o jinak položené, respektive sledovatelné akcenty. Nejdřív zaujme, že jak ,pačkovská“, tak ,grodkovská“ listina jsou vydány nejen téhož dne, ale mají i zcela identický (pochopitelně až na př́slušná jména) formulář, doslova s minimem byt' i jen nejdrobnějších maličkostí. Nadto jsou, zdánlivě logicky, datovány v tom kterém domovském městě, i když přivěšení pečetí vratislavského biskupa a tamní kapituly vedle pečeti toho kterého města signalizuje v tomto směru velkou opatrnost. Vzal jsem si proto do rukou jejich reprodukce ve výše zmíněné faksimilové publikaci $\mathrm{AČK}{ }^{10}$ a s jistým překvapením zjistil, že je už na první pohled patrno, že jsou jednoznačně psány jednou a touž písařskou rukou. ${ }^{11}$ Ale je třeba jít dále. Ve fondu AČK je několik dalších časově blízkých listin vratislavského biskupa Václava, které vznikly nikoliv ve Vratislavi, ale během jeho návštěvy v Praze koncem roku 1382 a počátkem roku následujícího. ${ }^{12} \mathrm{Z}$ toho nejméně dvě $\mathrm{z}$ nich jsou nad veškerou pochybnost psány totožnou písařskou rukou. ${ }^{13}$ Že členové biskupské kanceláře a ovšem

7 Viz T. Silnicki, Dzieje i ustrój kościola katolickiego, s. 281. Ke královu itineráři viz Ivan HLAVÁČEK, Das Urkunden- und Kanzleiwesen des böhmischen und römischen Königs Wenzel (IV.) 1376, Schriften der MGH 23, Stuttgart 1970, s. 392nn.

8 I. HLAVÁČEK, Das Urkunden- und Kanzleiwesen, s. 405. V létě 1381 tu strávil dokonce více než dva týdny, které ale kupodivu vykázaly jen minimum jeho písemné agendy. Tím spíše ale šlo nepochybně o bezprostřední osobní jednání jednotlivých stran. Viz A. HaAs (ed.), Katalog, č. 22.

9 Této epizodě a ovšem její významné prehistorii je věnována rozsáhlá starší literatura. Viz Wilhelm SchulTE, Die politische Tendenz der Cronica principum Poloniae, Darstellungen und Quellen zur schlesischen Geschichte 1, Breslau 1906; T. SILNICKI, Dzieje i ustrój kościola katolickiego, s. 275nn.; nověji Jiří SPĚVÁČEK, Václav IV. 1361-1419, Praha 1986, s. 140-142, zejména podle: František M. BARToš, České dějiny, II/6, Čechy $v$ době Husově, Praha 1947, s. 32n.

10 Věra BeránKová - Denko Čumlivski (edd.), Archiv České koruny. Edice faksimilii, V/1, 1378-1404, Praha 1980 , č. 1250 a 1251.

11 Už úvodní iniciála („Nos“) je charakteristická, nebot’ její první dřík je ve své polovině obtočen třemi širokými závity, které jsou v některých písemnostech zdvojovány.

12 Viz A. HaAs (ed.), Katalog, č. 26-29.

13 Jedna z nich je německá (AČK č. 1244 = A. HAAs /ed./, Katalog, č. 28), druhá latinská (AČK č. $1242=$ A. HAAS /ed./, Katalog, č. 26). 
i další členové biskupova dvora svého pána doprovázeli, je nepochybné. Proto je třeba jednoznačně konstatovat, že také obě městské listiny jsou písařsky produktem vratislavské biskupské kanceláře, a tudíž nevznikly v ohlašovaných místech vydání, nýbrž v režii vratislavské biskupské kurie. To je sice zajímavé, ale jde vlastně jen o začátek následujících úvah.

Nejdřív je však třeba uvést další nabízející se, ale zatím nezmíněné souvislosti. Týká se to nejprve listiny města Nisy (jež je datována 26. března roku 1383 a označuji ji jako $\mathbf{C}$ ), ${ }^{14}$ sídelního místa vratislavských biskupů, které bylo stejně jako obě predchozí města součástí tzv. „Bistumslandu“ vratislavských biskupů. Má stejné znění jako listiny $\mathbf{D}$ a $\mathbf{E}$ i s identickým ověrením a zpečetěním, je adresována rovněž králi Václavu IV. ${ }^{15}$ Je ale datována ve Vratislavi a i jejího ingrosátora lze bez jakýchkoliv pochybností ztotožnit s písařem úvodem zmiňovaných listin $\mathbf{D}$ a E. Výslovně konstatuji, že mluvím pouze o ingrosátorovi, nikoliv diktátorovi, ač se doslova nabízí anonymní diktátor biskupské kanceláře Václava Lehnického. Už jen těchto několik listin by bylo dostatečným podkladem k různým úvahám, nicméně jsou ještě další písemnosti, které vedou dále. Zejména to je o více než třicet (!) let starší listina z doby začínající vlády Karla IV. Týká se přihlášení se města Nisy z 1. listopadu 1351 (A) ${ }^{16} \mathrm{k}$ tomuto panovníkovi. Nejen ve stejném duchu, ale lze říci, že i po doslova obdobných, ba skoro totožných politických komplikacích, ba prímo eskapádách. To by bylo možno chápat. Ale je použito opět zcela identického formuláře, s jakým se setkáváme u písemností C, D a E pro Václava IV. z roku 1383. A posléze vstupuje do úvah i notárský instrument Mikuláše Petrova z Boleslawce (Bunzlau), vydaný 26. prosince 1382 (B) v Praze. ${ }^{17}$ Ten inzeruje čtyři listiny týkající se lenního vztahu vratislavského kostela $\mathrm{k}$ českému králi, předkládané jeho proboštem Mikulášem z Riesenburgu. Na prvním místě pak mezi nimi figuruje v našich souvislostech zásadní listina A. Zajímavá by ovšem byla i narace tohoto instrumentu; bohužel můj dotaz v tomto směru adresovaný tamnímu archivu zůstal bez odpovědi...

O čem tyto skutečnosti svědčí? Nejen že se jednoznačně ukazuje, že údaje o místu vydání obou textů $\mathbf{D}$ a $\mathbf{E}$ z května 1383 jsou doslova fiktivní. Naopak k jejich zpečetění - včetně listiny $\mathbf{C}$ - muselo dojít v prostoru biskupské vratislavské kurie, přesněji přímo v kanceláři, kam se dostavila (či spíše byla př́edvolána) delegace té které městské rady s př́slušným městským pečetním typářem. Přivěšením otisku městské pečeti tak aktivní úloha všech tř́ městských delegací, které se vypravily do Vratislavi, nejen začala, ale také vzetím na

14 AČK č. 1248 = A. HAAs (ed.), Katalog, č. 32.

15 Výjimkou je ovšem intitulace a pak datace. Ta tu totiž přichází ve formě datování průběžného, zatímco obě listiny květnové mají totožnou dataci, ale podle církevního kalendáře, jen s pouhou nevýznamnou variantou slovosledu.

16 Václav HrubÝ (ed.), Archivum Coronae regni Bohemiae Tomus II inde ab a. MCCCXLVI a MCCCLV, Pragae 1928, č. 211, AČK č. 375, který cituje i řadu opisů vložených do korunních kopiářů, což se nepochybně stalo i s výše zmíněnými listinami C, D a E. Ve výše citované knize prací R. Kosse - O. Bauera (edd.), Archiv Koruny české, I, s. 85-100.

17 Viz Wincenty Urban, Katalog dokumentów Archiwum archidiecezjalnego we Wroclawiu, I, Dokumenty oznaczone sygnaturami alfabetycznymi, Roma 1970, č. 732. Jde vesměs o texty, jejichž originály jsou uloženy v AČK. Jsou to: výše zmiňovaný text (A. HaAs /ed./, Katalog, č. 375), 1355, září 24 (tamže č. 484), 1358, listopad 29 (tamže č. 672n. - jde o dva ex.) a 1358 listopad 30 (tamže č. 674n., opět ve dvou vyhotoveních). O prŕslušném veřejném notáři Mikuláši Petrovu z Boleslavce, který pocházel rovněž z vratislavské diecéze a nepochybně delegaci vedenou Václavem doprovázel, viz Fritz LuscHEK, Notariatsurkunde und Notariat in Schlesien von den Anfängen (1282) bis zum Ende des 16. Jahrhunderts, Historisch-diplomatische Forschungen 5, Weimar 1940, s. 207, a Josef NuHLíčEK, Veřejní notáři v českých městech, zvláště v méstech pražských až do husitské revoluce, vyd. Ivan HLAVÁČEK - Markéta MARKovÁ, Praha 2012, s. 271, č. 898. 
vědomí př́slušných ustanovení o chování všech tří měst skončila. Právní závažnost těmto písemnostem pak dodaly pečeti vratislavského biskupa a jeho kapituly. Proč u $\mathbf{D}$ a $\mathbf{E}$ byl zvolen údaj, který zdůrazňoval místo vydání totožné s intitulací, se lze toliko dohadovat. Zřejmě to nebylo na základě impulsu biskupské strany, ale - pokud vůbec - tak na přání pačkovských a grodkovských představitelů. Víme totiž, že město Nisa jen o několik měsíců dříve a prostřednictvím stejného písaře - žrejmě bez problémů - jako místo vydání nechalo uvést skutečné místo př́slušného zlistinění, totiž Vratislav. Nicméně jde o konstatování věci z obecného hlediska nepodstatné.

Za důležitější ale považuji přes propast tř́ desetiletí naprostou textovou identitu všech čtyř listin, nad níž je třeba se zamyslet. U textů $(\mathbf{D}, \mathbf{E})$ z května roku 1383 by bylo možno předpokládat, že vznikly na základě nisského formuláře $(\mathbf{C})$, který byl koncipován v biskupské kanceláři, aby pak po dvou měsících mohl být využit pro obdobná přihlášení se k českému králi Grodkovem (D) a Pačkovem (E). Textově zcela identické přihlášení se Nisy ke Karlu IV. v roce 1351 (A) nabízí ale jiné možnosti interpretace. Tak zejména je už nyní zřejmé, že složité vysvětlení, za jakých okolností jsou uvedená města ochotna podporovat krále, není jakýmsi shrnutím tehdy vládnoucích poměrů po odeznění místního „schismatu“ a následné tzv. „popské války“, i když dosti zrételně vystihuje po jejich odeznění vzniklý kompromis. Formuláŕ listiny A pochází z doby, kdy se po biskupu Nankerovi z Oxy (1326-1341) ujal úřadu Přeclav z Pogorelly (1341/2-1376). Tehdy totiž docházelo $\mathrm{k}$ přechodu řady slezských knížectví pod vrchní vládu českých králů. Ten se během svých počátků maximálně snažil vyjít vstřríc zájmům Karla IV., potažmo českého státu. Současně ale pečoval o zajištění odlišných zájmů druhé strany, jejímž byl předním reprezentantem. Svým způsobem to byl jakýsi závěr vzrušených let čtyřicátých a počátku padesátých, které byly neseny sporem $\mathrm{v}$ záležitosti další provinční př́slušnosti vratislavského biskupství a celého tzv. „Bistumslandu“ tamních biskupů, nebot' Karel IV. usiloval, ovšem marně, o jeho převedení do svazku arcibiskupství pražského.

Diplomatika ale zajímá zejména jiná otázka, totiž to, jak a kde se uchovala povědomost o textu A z dob počátků Karla IV., který se nacházel už více než třicet let v Českém korunním archivu a byl vhodnou kompromisní předlohou pro tři listiny určené jeho synovi $(\mathbf{C}$, D, E) na závěr dalších vratislavských turbulencí: kolem tamní sedisvakance a následné „popské války“. Nabízejí se dvě možnosti. První je, že vratislavskému biskupovi bylo při jeho pobytu u královského dvora v Praze počátkem toho roku (1383) sděleno, respektive př́mo předáno, znění listiny $\mathbf{A}$, která se nacházela $\mathrm{v}$ AČKK jak v originálu, tak $\mathrm{v}$ opisu $\mathrm{v}$ některém $\mathrm{z}$ archivních kopiářů. A to $\mathrm{s}$ pokynem, aby vyžadované listiny konkrétních městských vydavatelů $(\mathbf{C}, \mathbf{D}, \mathbf{E})$ ve stejném znění, včetně průvodního přihlášení se biskupa a jeho kapituly, jako príijatelný kompromis byly po jeho návratu domů vyhotoveny ve Slezsku (v Praze pochopitelně nebyly k dispozici městské typáře) a zaslány do Prahy. Tak se i stalo. Možnost, že by tuto variantu navrhla dvorská kancelář Václava IV., se takřka nabízí, protože lze důvodně předpokládat, že korunní archiv sám byl v uvedené době uspořádán tak, aby potřebný text byl bez problému vyhledán. Víme totiž o tom, že Karel IV. někdy po polovině století ustanovil jeho archivářre ${ }^{18}$ a ten nepochybně „konal“, jak naznačují nejen

18 Dosvědčuje to formulářový text př́ślušného jmenovacího dekretu Karlova. Překlad pořídil Karel BeráNEK, vydáno s redakčním komentářem v úvodníku: K výroči Karla IV., Archivní časopis 28, 1978, s. 129-130. Jinak srov. R. Koss - O. BAuER, Archiv Koruny české, I, s. 80-81. 
různé staré archivní poznámky, ale zejména právě tehdy zakládané kopiáře. Protože ale všechny tř̆ listiny byly nutně ingrosovány ve Slezsku a zřejmě vesměs ve Vratislavi po biskupově návratu do Vratislavi, bylo by třeba předpokládat existenci textu (zda v originálu či v opisu nelze říci), který byl biskupu Václavu dvorskou kanceláŕí dán $\mathrm{k}$ dispozici. A protože ingrosátor těchto listin byl prokazatelně v biskupově průvodu v Praze, není zcela vyloučena ani možnost, že uvedené texty mohly vzniknout tam a ve Vratislavi byly posléze jen zpečetěny. Proti tomu ovšem mluví rozdílnost jejich datačních formulí a zejména už výše zmíněný notářský instrument (B). ${ }^{19}$

Druhou možnost lze sice odvozovat od předpokládaného dochování konceptu či opisu ve vratislavské biskupské kanceláři. Nejspíše by se tak mohlo ovšem dít ve formě textu zaneseného do př́slušného kopiáře, jehož existence je opravdu dosvědčena již před polovinou 14. století. ${ }^{20} \mathrm{Ale} v$ důsledku toho, co bylo řečeno výše, není potřebné to předpokládat, nebot' použití opisových předloh v AČK je takřka nad jakoukoliv pochybnost. Ostatně by ani nedávalo smysl předpokládat, že by z Vratislavi přinesený materiál byl opisován až v Praze a to dokonce ve formě notářského instrumentu, zatímco inzert $\mathrm{z}$ předloženého cizího materiálu má v této formě svůj smysl.

Pokud jde o vypovídací historickou hodnotu obou listin, pačkovské i grodkovské, není potřebí př́iliš mnoha slov. Vlastní, tedy formální vydavatelé tu do značné míry ustupují do pozadí, protože hlavní vazby jsou vedeny mezi panovníkem a vratislavským biskupem, jak tomu bylo ostatně již při př́ležitosti o třicet let starší listiny města Nisy. Nebot' ten potřeboval alespoň rámcové jištění pro v oněch listinách zmiňovanou, či spíše zdůrazňovanou podporu $\mathrm{v}$ př́ípadě možných útisků ze strany královské moci. Zároveň ale prokazoval prostřednictvím svých poddaných vstř́icnost panovníkovi nejen pro svou osobu, ale i jako závazek instituce, jejímž jménem jednal.

Touto sice hypotetickou, leč značně pravděpodobnou rekonstrukcí bylo možno pootevř́it okénko do jedné z funkcí stř̌edověkých archivů, o nichž víme velice málo a které leckdy mohou - když jsou správně interpretovány - náš pohled na historickou realitu výrazně modifikovat. Tyto funkce ovšem byly velmi rozmanité, jak ukazují četné vojenské či diplomatické události či okolnosti. Zde stačí upozornit jen na exemplární př́ípad habsburského rodinného archivu na hradě Baden a jeho osudy poté, co Habsburkové prohráli v roce 1415 se švýcarským Spř́iseženstvem. ${ }^{21} \mathrm{~A}$ je výzvou př́štímu zkoumání upozorňovat na archivy jako výmluvné, ale když nejsou dotazovány mlčící svědky. Zdaleka ne vždy je ovšem k dispozici dostatečně zřetelný materiál. Doufám, že tato sonda nabídla možnost uvědomit si, že přitom nešlo jen o dokazování již dř́ve zlistiněných práv, ale že archivy a jejich obsah mohly být i svým způsobem východiskem $\mathrm{k}$ vytváření nových právních skutečností.

Závěrem lze, jak doufám, zřetelně konstatovat, že AČK je tak jako málokterý jiný archiv už jen svou strukturou a ovšem i rozsahem takřka ideálním předmětem diplomatického, respektive archivně-diplomatického studia, ovšem s výrazným dopadem jak na poznání

19 Bylo by ovšem potřebné provést jeho kolaci s texty $\mathbf{C}-\mathbf{E}$, aby se př́padně dala přednost textu $\mathbf{A}$. To by ovšem činilo existenci textu $\mathbf{B}$ zbytečnou.

20 Pozornost mu v rámci svých analytických kopiářových studií věnoval zejména Bronislaw Turoń, ,Liber niger", kopiarz biskupstwa wrocławskiego, Acta Universitatis Wratislaviensis 126, Historia 19, 1970, s. 46-96.

21 K tomu srov. nově Carmen Tellenbach, Das Habsburger Archiv nach seinen Inventaren, in: Christian Hesse Regula Schmid - Roland Gerber (eds.), Eroberung und Inbesitznahme. Die Eroberung des Aargaus 1415 im europäischen Vergleich, Ostfildern 2017, s. 237-247. 
historie správní, tak politické. Hovoří nejen o sobě, ale leckdy také o př́ijemcích či vydavatelích listin, které v něm, zdánlivě per nefas, přicházejí (ale i nepřicházejí). Týká se to sice zejména listin lenních či holdovacích, ale lze tu nacházet i materiál takřka výbušné povahy politické. Mám tím na mysli zejména všeliké smlouvy, zejména státní. Ale ovšem i vlastní listiny př́mého zřizovatele (v našem prípadě českého panovníka) si tu zaslouží zvláštní pozornost. To se samozrejmě týká originálního uchování; u opisově (v kopiáríich) dochovaného materiálu třeba pochopitelně postupovat jinak, protože může jít o písemnosti, jejichž uvedení v život bylo více než pochybné, nebo k jejichž kasaci došlo v důsledku historického vývoje, o němž není bližší povědomost. To je ale už zcela jiná kapitola.

IVAN HLAVÁČEK

\section{Miscellanea ex Archivo Coronae regni Bohemiae. Diplomatische Herkunft und Aussagewert zweier Urkunden der schlesischen Städte Patschkau und Grottkau aus dem Jahre 1383}

\section{ZUSAMMENFASSUNG}

Im Böhmischen Kronarchiv liegen u. a. zwei Urkunden der Städte Grottkau und Patschkau von 1383, in denen die Stadtvertreter dem böhmischen König Wenzel IV. Treue und, falls nötig, Hilfe versprechen. Sie sind aus diplomatischer Sicht interessant, da sie mit gleicher Hand geschrieben sind, die sich als die Hand der Breslauer bischöflichen Kanzlei entlarvt. Darüber hinaus hat sich gezeigt, dass ihr Wortlaut genau dem Text einer dreißig Jahre älteren Urkunde der Stadt Neiße, die ebenfalls im genannten Archiv liegt, entspricht. Es hat sich also gezeigt, dass diese Urkunde als Vorlage für die beiden Stücke aus dem Jahre 1383 diente, die während des Prager Aufenthalts des Breslauer Bischofs auf Grund der Neißer Überlieferung im Böhmischen Kronarchiv entstanden, dann nach dessen Heimkehr nach Breslau dortselbst ausgefertigt (d.h. auch besiegelt) und erst anschließend nach Prag geliefert wurden.

\section{Ivan Hlaváček}

Filozofická fakulta UK, Praha

ivan.hlavacek@ff.cuni.cz 